811.163.41'366.58

811.163.41'367

https://doi.org/10.18485/sj.2017.22.1.20

РАДОЈЕ Д. СИМИЋ

Универзитет у Београду

Филолошки факултет
Оригинални научни рад

Примљен: 15. 07. 2016.

Прихваћен: 15. 12. 2016.

\title{
УЧЕЊЕ СТАРИЈИХ ФИЛОЛОГА О УПОТРЕБИ И ЗНАЧЕЬУ ГЛАГОЛСКИХ ВРЕМЕНСКИХ ОБЛИКА - И ЮЕГОВ ЗНАЧАЈ
}

Проблем значења и употребе глаголских облика слободно се може рећи да је најсложенији од свих лингвистичких питања која се тичу структуре језика и природе језичког израза. Код нас се у граматичкој литератури још увек највиши значај придаје учењу А. Белића о глаголском индикативу, релативу и модусу, али са многих страна долазе приговори да ова трочлана схема не даје довољно добру подлогу за прецизнију карактерологију глаголских значења и употребе. Прилог предложен читаоцу представља део, или боље рећи први степен, подухвата који се може схватити као покушај - и ништа више - да се изнађу адекватнији методи за истраживања у овој значајној области. Полазимо од учења старијих филолошких школа, које код нас представљају Т. Маретић и А. Мусић, значајни проучаваоци Вукова и Даничићева језика, а њихово учење је оставило трага у каснијим радовима. Ми ћемо се задовољити приказом њихових резултата, и понеком напоменом која нам се чинила неопходном за разумевање онога што тумачимо.

Кључне речи: време, садашњост (права, неправа), историјско време; приповедање, јављање, саопштавање (приопћавање).

*jelenajo@bitsyu.net 


\section{1. ПРЕТХОДНЕ НАПОМЕНЕ}

1. Историја синтаксе, по обавештењима проучавалаца класичне старине, почиње од Аполонија Дискола, а како каже Б. Делбрик (1893), она је првобитно подразумевала учење о „конструкцији” уопште, тј. о начинима груписања речи у више целине без упуштања у посебна својства и класе тих конструкција, пре свега у проблем реченице и њеног односа према нереченичним (и субреченичним) облицима груписања. Касније се издваја учење о реченици као учење о субјекту и предикату - логички дефинисаним појмовима, на једној страни, и у једном смеру њеног посматрања, и на другој: о конструкцији „заокруженог смисла” уопште, без улажења у природу делова по себи. Постепено се, међутим, рађају идеје о врстама реченичних делова, и у вези с тим о „деловима говора” : супстантиву, адјективу, вербуми итд. Бругман Делбрик (1893) углавном се на том плану баве синтаксичким питањима.

2. Врло је тешко било разграничити учење о врстама речи од онога о реченичним члановима, а посебно оно о природи субјекта, предиката итд. - или у крајњој линији све ово од сазнања о употреби облика именских и глаголских речи у реченици, њиховом значењу, функцијама итд. Франц Миклошич у својој Поредбеној синтакси словенских језика (Миклошич 1883) - синтаксу схвата као науку о „значењу врста речи и облика речи”, но ипак не запоставља сасвим учење о реченици и њеним члановима, него о томе даје напомене поводом употребе нпр. падежа: уз номинатив о субјекту, уз акузатив о објекту итд. У расправи о глаголским облицима Миклошич разликује самосталне реченице од зависних, и мисли да се облици често друкчије понашају у једној а друкчије у другој врсти. Иначе, Миклошич препознаје различите категорије које ће и у каснијим радовима бити од значаја и које ће се сврставати бар у област „правог” и „неправог” значења.

2.1. По ауторовим налазима (стр. 770-784), „презент дуративних глагола означава радњу која траје у садашњости”, и одговара на питање „шта чиниш?” (glagolją vamъ) ${ }^{1}$; често се употребљава да означи футурску радњу (ešte malo vrême sь vami esmь, i idu kь poslavbšjumu me); „Презент итеративних глагола означава радње које се обичавају догађати, а затим и оне које су неограниченог трајања" (ni vъžigajątъ svêtilnika i postavljajątъ jego podъ spudomъ); презент перфективних глагола „означава у зависним реченицама футур” (jegda obręštete, povêdite mi); често, „наиме у пословицама, означава перфективни презент радњу која није ограничена ни на које време, или тачније: радњу која може настати у свако време, и под одређеним околностима стварно настаје" (ašte sêno bogъ odêjetъ tako); у „новијим језицима сусреће се старословенском језику непознат историјски презент” (kad bude ujutru, carev sin ustane)...

\footnotetext{
${ }^{1}$ Примере преносимо у Миклошичевој транскрипцији.
} 
2.2. Имперфект (784-786) „означава радњу која је у прошлости трајала, понављала се или радњу коју је неко био науман вршити, или покуша(ва)о" (konji oko njega jednako skakahu i vrištijahu).

2.3. Aorist (787-799) „означава радњу која се десила у прошлости” (i postavi ga navrh crkve); означава и радњу „која само што није извршена, стање које само што није настало: блиска будућност представља се као прошлост" (ja otidoh u Moraču gornju do Tušinje, do moje starine, pokupiću vojsku od Tušinje).

2.4. Имперетив је (790-799) „по пореклу, па стога и по значењу, стари оптатив. Основни појам оптатива јесте жеља”.

2.5. У поглављу о „партиципу перфекта активног” Миклошич обрађује све облике са радним придевом у свом саставу (800-818).

a) Перфекат отприлике по Миклошичу означава неодређену прошлост (sъtvorilъ li esi volju moju?).

б) Значење плусквамперфекта не дефинише се јер се сматра познатим.

в) Кондиционал је веза партиципа „са аористом by (,бы”) има модалну функцију нереалности. Та конструкција показује да нешто постоји само у мислима”. „Означава жељу да се нешто деси или не деси, даље неки захтев или забрану” (jaruj togo da byhъ ne vêdêlъ).

2.6. Миклошичев преглед више је практичан него теоријски по смислу, јер се углавном тиче постојања или непостојања облика у старсловенском и посебним словенским језицима, и употребе у одређеним временским или модалним значењима, а не могуће систематизације употребних вредности. Углавном се дакле тиче синтагматика и прагматике, а у позадини остаје парадигматика ових облика.

3. Индоевропска и словенска филологија у старије доба се ослањају наравно на германистику. Колико је германистичка литература од помоћи у тој области показује се у граматикама немачког језика. При руци нам је дело једнога од најугледнијих научника тих генерација, Немачка граматика Хермана Паула (Паул 1956), која спада и данас у ред „класичних приручника за германисте".

3.1. Паул најпре укратко формулише „теорију времена” (Tempustheorie), коју ћемо ми, због њеног значаја, скоро у целини овде цитирати.

Чињени су различити покушаји да се времена у индогерманским језицима доведу у неки логички ред. Али већ унапред није могуће претпоставити да се тај ред може прецизно успоставити на основу стварног стања. Код граматичког времена ради се увек о релативном односу према неком временском моменту. Као таква нуди се најпре садашњост. За истовременост са тим временом у идг. 
је постојао презент, за претхођење перфекат, за оно што следи футур. Може се међутим за исходиште узети неки моменат прошлости. Истовременост са њиме у идг. је означавао имперфекат, што ипак није била његова једина функција, за претхођење плусквамперфекат; за оно што следи овоме моменту није постојао посебан облик, него је преостало само, што се делимично и дешавало, да се ово обележи описно. Може се поћи и од неког момента у будућности; за означавање истовремености са овим моментом могао је бити примењен опет футур, за претхођење је био на располагању фут. егзактни, а за оно што следи није постојао посебан облик. Ове одреднице тичу се заправо индикатива. Императив се наравно увек односи на будући догађај; исто делимично вреди и за конјунктив и оптатив... (IV, 64).

3.2. Затим Паул разматра партиципе, а после њих „замену изгубљених облика описима" (IV, 136 и д.).

a) Значење перфекта тумачи резултативним значењем партиципа перфективних глагола. „Тако он је пао првобитно је значило „он лежи после пада": Али у току времена дошло је до померања значења, па се овај опис почео употребљавати да изрази и да се неки догађај десио, ако последице тога и не трају више...” (IV, 137).

б) Футур је код Паула описан прво у историјској перспективи германског перифрастичког комплекса и његовог развоја, не дефинишући његов коначни семантички лик (IV, 147). Што се тиче значења, Паул скреће пажњу да се футур употребљава и за „енергичну заповест”: Du Wirst (sofort) das Haus verlassen; - „неизвесне догађаје”, у прошлости: Karl wird ohne jeden Zweifel dagewesen sein (IV, 153), итд.

3.3. О презенту Паул утврђује, сем значења „садашњости” да се употребљава „у општим безвременским реченицама као човек је смртан..., ко је храбар - добија" (IV, 150).

а) „Реченице као он храмље, пије, пуши, игра, јаше, говори енглески двосмислене су јер се односе колико на једнократни догађај толико и на неку навику. И изван овога најпре долази да размислимо да је садашњост само један тренутак. По томе се по себи разуме да код имперфективних глагола догађај почиње у том тренутку, а да затим траје и даље. Помоћу ближих одредница може се упутити да је догађај који се наставља у садашњости - почео раније, исп. он спава (то знам) већ дуго..." (IV, 151)

б) Чест је презент за будућност: Фрии долази такође? - Ти ћеш га примити лепо кад дође (IV, 152). 
3.4. Паул извештава да у германском облик тзв. претерита има вредност и аориста и имперфекта. ,Зачеци извесног разграничења заправо су се јављали. Обично је смисао имперфекта имао облик was са партиципом презента, док je ward са тим партиципом био са смислом аориста: da ward das ganze Heer laufend und schrieen und flohen” $(\mathrm{IV}, 154)=$ „онда јурну цела армија и викаху и трчаху".

3.5. Паул стриктно разграничава зависне реченице од самосталних, (в. посебно IV, 312-329), што је у германским језицима неопходност која долази од особина самог језика (између осталог, тамо је веома развијено тзв. слагање времена, које у словенским језицима нема већег значаја).

4. Судећи по ономе што смо нашли у прегледаним делима, теоријски напредак у области проучавања значења и употребе глаголских облика све до XX века није нимало спектакуларан. Знало се за тројаку временску могућност оријентације говорника приликом употребе глаголских облика: садашњост, прошлост и будућност. Знало се затим и за двојаки временски ослонац при оријентисању у времену граматичких облика: први је „садашњост”, а други „прошлост” или „будућност”. Знало се такође и за употребу модалних облика, као и за транспозицију временских облика у модалне. На крају, истраживачи су све ове категорије везивали по реду за овај или онај облик, а перифрастичке обрте нису третирали као облике него их у истраживању сматрали употребним вредностима партиципа или инфинитива.

\section{2. УВОД}

1. Оно што су двојица хрватских класичара и слависта, вуковаца по ставу о књижевном језику Срба и Хрвата, живећи и радећи у време превласти најпре историјско-компаративног па затим младограматичарског приступа језичкој проблематици ${ }^{2}$ - учинили између осталог и за познавање употребе и значења глаголских облика, не сме бити заборављено ако се желимо примаћи суштини овога језичког система. Њихове теоријске поставке директно су ослоњене о учење Б. Делбрика и Ф. Миклошића (868-1874), дакле индоевропеистичке и славистичке синтаксичарске школе, али су двојица аутора наслеђена схватања унапредили, и то видно.

2. Завршавајући свој посао на „Прилозима науци о употреби времена у српскохрватском језику", Мусић је, на нешто више од десет година пред своју смрт (1927), написао следеће прескромне речи: „Дошавши на крај ових Прилога видим, колико оно, што сам њима постигао, заостаје за оним, што сам

${ }^{2}$ Енцикопедија Југославије 6, Загреб 1965: Т. Маретић, Вировитица 1854. - Загреб 1938. - А. Мусић, Крка 1856. - Загреб 1938. 
намјеравао постићи. Стога ни сам не мислим, да сам свагдје казао посљедњу ријеч. Бићу задовољан, ако се могбуде рећи, да сам добро зацртао бар главне црте науци о временима у српско-хрватском језику, да сам јој начинио бар добар оквир, ако га и нијесам свагдје добро испунио...” (III, 54-55).

3. Мусићев, као и Маретићев, допринос далеко је изнад ове више него суздржане оцене. Прво што ваља са пуно признања рећи, јесте да је Мусић, као пре њега и Маретић, своју пажњу усмерио искључиво на оно што се мора назвати основицом српскога и хрватскога књижевног језика - то су Вукова и Даничићева дела и њихова језичка подлога - језик штокавских крајева. Друго, широко заснивајући свој чврсто на грађи заснован пројекат, Мусић је најпре утврдио да употреба глаголских облика одговара врстама текстова које је имао у рукама (нешто што подсећа на данашње „функционалне стилове”): једна је слика тих односа у народним песмама, друга у приповедној прози, трећа у преводима Светог писма, четврта у историјским списима Вуковим и Даничићевим. Даље, Мусић разликује оно што бисмо ми данас назвали (наратолошким) жанровима: он при томе четворочланој Маретићевој - узгред и нејасно оцртаној схеми (приповедање, саопштавање, јављање, спомињање - в. тамо) супротставља двочлану (приповедање и разговор), строго и доследно разграничавајући ове две категорије. И на крају, по њима обојици, значајна разлика у употреби облика постоји између самосталних и несамосталних (зависних) реченица. Битна чињеница која се заправо мора сматрати доминантом у овом комплексу - јесте да глаголски облици у свим наведеним категоријским сферама углавном чувају своје системске вредности, а варирају значење у зависности од врсте реченица (,лингвистичког контекста", како би се рекло данас), а и односе у учесталости употребе са тим вредностима, у зависности од „функционалног” стила. О тим вредностима и Мусић и Маретић говоре анализирајући конкретну грађу, па ћемо их ими тако приказати.

4. Не знамо колико су двојица вршњака били истомишљеници, али је факат да се Мусић у својим радовима у великој мери држи истих принципа које је Маретић развио у својој Граматици, и да у приступним изјавама помиње Маретићеву Граматику (али неки његови радови претходе овој). Ми ћемо најпре приказати Маретићеве налазе, а онда ћемо узети у разматрање Мусићеве радове (I-III). У закључку овог рада покушаћемо да дамо кратку оцену доприноса двојице знатних синтаксичара општој теорији о употреби и значењу глаголских (временских) облика. 


\section{3. ПОГЛЕДИ Т. МАРЕТИЋА}

1. Маретић о синтакси (нарочито о „мудровању о реченици”) није имао повољно мишљење, али јој је у својој граматици посветио велики простор (Маретић 1963: 411-665), и пуну пажњу. По свом општем обичају, није се упуштао у теоријска разматрања мимо анализе грађе, тако да систем појмова и категорија морамо апстраховати из примене у обради материјала.

1.1. Преглед употребе презента почиње уводећи термин „права садашњост".

a) Презент се употребљава „говори ли се о нечему што доиста јест у оно вријеме кад се говори... За такву садашњост може се употријебити презент само трајних глагола, нпр. киша пада, киша не пада, пада ли киша?"

б) „Презент трајних глагола узима се и онда кад се казује што је на којој (сачуваној) слици или кипу или што је у којој (сачуваној) књизи или писму, јер онај ко то казује има ону слику или ону књигу доиста пред собом или бар у мисли...: на највише овијех стећака имају изрезани различни ликови, нпр. с лица људи на коњима с мачевима и с копљима у руци, гдјекоји тјерају јелена и већ га стигли и копљем ударили; а с наличја стоје три човјека, па двојица држе међу собом крст, а трећи се ухватио за њих као да играју...”

1.2. „Неправа садашњост” стоји према „правој” као временски неограничено значење према ограниченом.

a) Први Маретићев такав случај тиче се неограниченог понављања: „Говори ли се о чему што се догађа свагда кад год се прилика деси (дакле не само у садашњости него и у прошлости и у будућности), онда је то неправа садашњост, нпр. у Момчила сестра Јевросима, готови му то господско јело, прије њега јело огледује; у Момчила девет миле браће, они њему рујно вино служе, прије њега сваку чашу пију. У вријеме кад Момчилова љуба то говори, можда се ниједна од наведених радња не врши, Видосава хоће да каже: у свако вријеме кад год треба готовити и огледовати јело Момчилу, готови га и огледује Јевросима, а иначе ради шта хоће, Јевросима је и досад то чинила, а чинит ће и одсад".

б) Пословички презент само је варијанта „неправог”. Маретић - не помињући то у вези са горе описаним случајем - утврђује сада: „За неправу садашњост служи презент и трајних и тренутних глагола...”: - рало и мотика свијет храни; - вино и мудрога побудали... 
в) Сада додаје да се, „и ван пословица”, сем „презента трајних глагола”, „за неправу садашњост...”, узима и презент „тренутних”: имовина често растави пријатеље и род, одвоји човјека од бога, помрачи му душу...

1.3. У даљој расправи Маретић заправо привремено напушта чисто лингвистички терен, и уводи појам „хисторичког презента”, тврдећи да се он употребљава „у приповиједању” (дакле стилски издвојеној категорији):

a) „Хисторички презент зове се онај који се употребљава у приповиједању прошлих догађаја (у приповиједању, а не у приопћавању или јављању онога што се догодило...)”3: - Стефан Душан I, цар српски, осим млоги други земаља узме од Грка сву Маћедонију осим Солуна, Тесалију од Негропонта, Етолију, Акарнанију, Епир и Арнаутску и назове се царем српским, грчким, бугарским и арнаутским...

б) Сматрамо врло важним што је Маретић утврдио да „се хисторички презент (од тренутних глагола) узима за догађаје који су се у прошлости обичавали догађати, тј. нису се догодили само једном већ неколико пута...": - био један цар па имао пред двором златну јабуку, која за једну ноћ и уцвета и узре и неко је обере... - У односу на „неправо време" како га Маретић схвата, дакле на категорију временске неограничености, постоји како видимо и тип временски уоквирене те исте категорије...

в) Маретић установљава и појам ,релативног презента”.

в1) На првом месту по учесталости стоји релативни презент перфективних глагола; он се употребљава „за догађаје који су се догодили прије другога којег догађаја који се такођер спомиње": - тако се Бећир-паша избави и под саму зиму отиде у Босну само с неколике стотине људи, а остала му војска сва пропадне у Србији...

в2) На другом месту је такав презент имперфективних глагола, који је много ређи код Вука, и којим „се изриче релативна прошлост, тј. права прошлост према времену у које се што говори, али према времену о ком се говори то је садашњост...”: - кад буде испред поноћи, он се пробуди и погледа на јабуку, а јабука почела већ зрети, сав се двор сјаје од ње... - Значило би да се перфективни релативни презент разликује од имперфективног по томе што означава прошлост у односу на неки прошли моменат, док онај други значи истовременост. Ипак нам се чини

${ }^{3}$ При томе упућује на поглавље о аористу, о чему в. у даљем нашем тексту. 
да је тумачење перфективности као обавезне „готовости”, „извршености” (в. даље о аористу) - недовољно прецизно, и последица је схватања перфективности као искључиво релационо временске категорије. Пре би се рекло да у примеру који Маретић наводи обележени презент „пропадне” означава радњу везану за исту временску ситуацију као и онај у однос са којим га Маретић ставља („отиде”), а да је сукцесија овде сасвим потиснута у позадину. Према томе: презент релативни употребљава се на исти начин и код перфективних и код имперфективних глагола: за радње које се дешавају у дато време прошлости (или будућности). Овде је битна истоветност временске ситуације, а не сама истовременост.

в3) „Кад је којим прошлим временом прошлост довољно назначена, онда Вук у зависним реченицама прошлост често изриче презентом, рјеђе у успоредним... У његову рјечнику код „справа” читамо: слугама и слушкињама што дарове доносе давало се што да пију. У том примјеру облик доносе не значи садашњост, него прошлост. Вук мјесто да каже: што су дарове доносили (или: што дарве доношаху), узима доносе, јер је прошлост у главној реченици назначена обликом давало се". - То је заправо иста категорија као горе.

г) Не каже аутор које је врсте „презент за будућност” у примерима као: - будући да ће у нашим земљама сунце оба пута помрчати ноћу, а месец дању, зато се ни једно не може (= неће моћи) видети.

д) Исто вреди и за презент у зависним реченицама као: - све ово даћу теби ако паднеш и поклониш ми се. Или: - па ћемо сутра, пошто се лепо преправимо, ударити на Турке. Или пак: - неки се завјетују у болести или у другој невољи да не једу никад рибу у среду и у петак...

1.4. На другом правцу скретања са почетне линије разматрања презента јесте и помињање „хисторичког презента” у различитим зависним реченицама: последичним (ушавши у Београд тако се обогате обојица да постану најбогатији људи у Србији), временским (како га из далека угледају, повичу на њ да стане), допусним (... али се Срби одрже, премда изгубе неколико знатни људи), узрочним (прођу с миром кроз Турке, јер нигдје пушка не пукне), релативне (Он раширено, а неутврђено царство српско раздијели на војводе и кнезове, које његов осамнаестољетни син и насљедник Урош не буде кадар под уздом држати...). - По свој је прилици оправдано разграничење „приповедачког” презента од „историјског” - што је у каснијим истраживањима запостављено као проблем. 
2. Аорист и имперфект по Маретићу употребљавају се за прошле (в. даље), али и за садашње догађаје, праве и неправе.

a1) „Веома се ријетко аорист узима за праву садашњост”: - о чу ли ме (тј. чујеш ли ме), мој брате Стефане.

а2) „Врло је риједак имперфекат за праву садашњост”: - а ви откле бесте? (тј. откле сте?).

а3) „Аорист се налази у пословицама за неправу садашњост”: два лоша избише Милоша.

a4) Аорист је способан да изрази и будућност: „Каткад се аорист употребљава за будуће догађаје, особито за онакве који се држе за сигурне и који су готови да се сваки час догоде (али се још нијесу догодили у вријеме кад се говори)": - Господе, избави нас, изгибосмо ${ }^{4}$.

б) „Слабо је обичан имперфект за изрицање релативне прошлости”: - видје их гдје се мучаху (тј. гдје се муче) веслајући, јер им бијаше противан вјетар.

2.1. Но аорист и имперфект добили су код Маретића посебно место, и посебно објашњење. Код њих је, прво, поведена расправа о употреби у различитим врстама текста, и друго, у различитим врстама излагања ${ }^{5}$.

а) Што се тиче првог, Маретић овако резонује: „У јужним крајевима” ови су облици чести „У обичном говору, а у осталим крајевима слабо. То се лијепо види из Вукових народних приповједака, гдје су ова два облика много обичнија у приповијеткама из јужних крајева неголи у онима које су из источних. У народним пјесмама (које не приказују вјерно обични говор) врло су обични и аорист и имперфект, - и ја мислим да се у много случајева узимају та два времена поради потреба стиха, тј. ондје гдје стих не допушта узети перфект, па је аналогија такових стихова учинила те су аорист и имперфект продрли и у стихове у којима би могао (с обзиром на број слогова) стајати и перфект. У Вукову пријеводу Новог завјета има и једног и другог облика големо мноштво, зацијело поради црквенославенскога текста, који их има такођер сву силу и којега се Вук држао као у многоме којечему другом, тако и у овоме. За Вуковим пријеводом Новога завјета повео се Даничић у своме пријеводу Старога завјета, те оне облике употребљава врло обилно. У осталим Вуковим дјелима (па и у његовим писмима и преписци) ријетки су - према Новом завјету - поменути облици, особито имперфект”.

\footnotetext{
${ }^{4}$ Боље би одговарао пример који је Маретићу био на располагању, али га он није приметио: - Ви идите двору бијелома, // а ја одох (= управо одлазим, крећем) своме винограду, // винограду, моме рукосаду...

${ }^{5}$ Подробније о томе в.: Јовановић и Симић 2015.
} 
б) Кад је реч о другоме, Маретић тврди: „Када казује што је у прошлости било, то може да буде приповиједање или приопћавање или јављање или спомињање"..

б1) „Аорист (и имперфект) се у приповиједању за догађаје који су се догодили у прошлости, значи дакле исто што и хисторички презент и перфект...”: - Родитељи његови иђаху сваке године у Јерусалим о празнику пасхе. И кад му (тј. Исусу) би дванаест година, дођоше они у Јерусалим по обичају празника; и кад дане проведоше и они се вратише, оста дијете Исус у Јерусалиму, и не знаде Јосиф и мати његова, него мислећи да је с друштвом, отидоше дан хода и стадоше га тражити по родбини и по знанцима. И не нашавши га вратише се у Јерусалим да га траже, и послије три дана нађоше га у цркви гдје сједи међу учитељима и слуша их, и пита их, и сви који га слущаху, дивљаху се његову разуму. - „Мјесто аориста (и имперфекта) у приповиједању може се свагда узети хисторички презент...”

б2) „Приопћавање”: снио сам, кнеже, да ти јашеш на коњу, пак загази у једно велико блато и заглиби се, а ја се деси близу тебе, а ти ме побрати, те те извади из блата.

б3) Мисли да „гдје је приопћавање прошлих догађаја, тамо се хисторички презент ни од тренутних ни од трајних глагола не може узети". На први поглед се чини је у наведеном примеру могуће аорист заменити презентом. Верзија: - снио сам, кнеже, да ти јашеш на коњу, пак загазии у једно велико блато и заглибии се, а ја се десим близу тебе, а ти ме побратии, те те извадим из блата - није неприхватљива? - Али иако две наведене Мартеићеве категорије у начелу нису тако различите. Али кад се сетимо маретићеве разлике између „приповедачког” и „историјског” презента, онда нам суптилна разлика ипак постаје видљива: аорист нити је идентичан овде са приповедачким, нити са историјским презентом, иако би требало да одговара овоме другом.

64) „Јављање”: - уједанпут оборе ватру из пушака и стану викати: бјежите! разби нас ајдук Вељко!

65) „Спомињање”: - ...jа сам вам неколико пута писао и говорио да се умирите и зулума оканите, а ви ме до данас не послушасте; - посла различна разговора и договора рече Молер: е брате Милошу! ми у име бога опет устасмо на Турке и народ с Турцима завадисмо; него ко ће бити старешина овоме народу? - дотрча к Милошу запомажући: помагај, господару, за бога! шта се то 
чини сад! ми за тобом пристасмо и с Турцима се завадисмо, па сад ајдуци да нам суде и браћу нашу да бију.

б6) „Јављање” и „спомињање” заправо ваља сматрати варијантама аориста „за садашњост”. - Оба пута он означава радњу која је везана за садашњу ситуацију, али претходи самом акту говорења...

2.2. Као и презент (1.3-б), по Маретићу се и имперфект употребљава „за трајне догађаје који су се у прошлости обичавали догађати”: - ондје се скупљаху сва стада, те пастири одваљиваху камен с врата студенцу и појаху стада... - као и „за трајне догађаје који су се у прошлости понављали”: - често књиге земљу прехођаху...

3. Напомену заслужује Маретићево запажање да је „хисторички презент” практично замена претеритаิ (ариста ${ }^{6}$ и имперфекта) и перфекта, онда када им се значења подударају, као и обрнуто. Перфекат (I) „може се за прошле догађаје свагда узети мјесто презента хисторичког... и мјесто аориста...”

a) Али перфекат није увек заменљив поменутим облицима: „Има случајева кад се мјесто перфекта никако не може узети ни хисторички презент ни аорист ни имперфект. То је онда кад се изриче догађај који се додуше догодио у прошлости, али му посљеци или плодови трају још у вријеме кад се говори": - кажу да таквог вукодлака нађу у гробу, а он се угојио, надуо и поирвењео од људске крви... - То је очито перфекат за неодређену прошлост...

б) „Перфектом се може изрицати релативна прошлост, тј. догађаји који су прошлосадашњи према оном о коме се или о чему се говори, а према ономе ко говори у правом су смислу прошли": кад ком отиђе, а он устане опет да дохвати кокош и погачу да једе, али се оно све претворило у корњачу...

в) „,..перфекат може се узимати мјесто плусквамперфекта”: - Мачвани ударе управо у варош, а Љешничани, који су онако на гласу пушкари, а сад испративши жене и ђецу само војници остали и утврдили се, дочекају ји и узбију натраг...”

${ }^{6}$ „У приповиједању може се свагда узети хисторички презент од тренутних глагола...” - Ми ћемо за аорист и имперфекат без образложења узети термин „претерити”, а за перфекат и плусквамперфекат - „перфекти”. Напомињемо да Маретић за футур други узима назив „перфекат II", што с обзиром на његово значење никако није погрешно - али ћемо ми задржати данас у нашој граматичкој литератури уобичајен термин „футур други”. „Перфектом другим” логично би било назвати плусквамперфекат. 
3. Маратић посебно помиње употребу облика футура са да+презент „за изрицање будућности": - он нека поправља српски језика, а ја ћу да учим и да се трудим онако писати као што је најобичније у народу․

a) Футуром „се често изриче оно што се може догодити, па се и догађа свагда кад год се прилика деси": - кад му послови допусте, nоходиће сваког од нас, па му прича занимљиво...

б) „Мјесто презента кад значи праву садашњост слабо се употребљава футур": ко у овоме догађају не мари за свој народ..., ономе ћу казати (тј. ја му управо сад кажем)...

в) „Често се футур узима за догађаје у прошлости који су имали или се спремали да буду. То је релативна будућност, тј. будућност према којему прошлом догађају који се спомиње, али према времену у које се говори, то је прошлост, само каснија него она друга": - Мачвани подигну се и ударе на Љешницу, но прије него што ће ударити, поизопијају се...

г) Футур се каткада „узима у приповиједању”: - једном стане се цар разговарати са својим синовима: куд се то дева род с наше јабуке? На то ће рећи најстарији син...

4. „Плусквамперфекат се узима и у главним и у зависним реченицама за догађаје који су се у прошлости догодили прије других који се такођер спомињу": - дође са своја неколика момка у Смедерево те оплијени некакве Турке који су се били предали Србима.

5. Маретић футур други, рекли смо горе, назива перфектом другим.

a) Утврђује да се „Узима за прошлост и значи исто што и перфект”: - питај, мати, доброга јунака, а је ли се досад оженио; ако бог да и срећа донесе, да с не буде јоште оженио, ја ћу млада баш за њега поћи...

б) Тек на другом месту помиње аутор да овај облик „од трајних глагола, pjeђе од тренутних, узима се (само у зависним реченицама) и за догађаје који ће у будућности бити истодобни или прошасти према другим догађајима који се спомињу": - Што се г. Светић буде више врияо и коприао против онога мога суда, он ће се све више заплетати...

6. Маретићев приказ глаголских облика у Вуковим и Даничићевим делима значи извесно унапређење општег знања о овим темама како је приказано у почетним нашим разматрањима. Унапређење се огледа најпре у прецизирању судова које је могао преузети, и које је сигурно преузимао од својих претходника, као и у подробнијим анализама грађе. Унапредио је Маретић затечена

${ }^{7}$ В. о томе облику: Симић 2016. 
схватања и увођењем у расправу, пре свега о аористу и имперфекту, појмове које смо ми назвали „жанристичким”. И на крају, Маретић јасније од својих претходника истиче стилистичке категорије „хисторичког” и „пословичког” презента, аориста итд.

\section{4. УЧЕЊЕ А. МУСИЋА}

1. У претходним напоменама рекосмо да - по схватањима наших аутора - глаголски облици своје опште употребне вредности добијају у систему значења, а разлике настају или у варијацији значења зависно од контекста, или пак у фреквенцији тих категорија у овој или оној употребној сфери. Мусић је своја схватања о томе приказао у одвојеној анализи грађе српских народних песама као једног комплекса (I), те превода Светог писма као другог (II), и народних приповедака као трећег (уз овај је додат кратак опис Вукових и Даничићевих историјских списа) (III). Најпре ће код нас бити речи о Мусићевим налазима у вези са народним приповеткама, а онда ћемо се сасвим кратко осврнути на друга два (од три) истраживачка комплекса.

2. У предговору своје студије (I, 112) напомиње да је „са потпуном филологичком спремом и на основи обилне грађе обрадио употребу времена Маретић у својој Граматици и стилистици хрв. или срп. језика, Загреб 1899...” (I, 112). „У прилозима, које с овом расправом почињем, радиће ми се поглавито о томе, да одредим разлику у употреби времена... у сваком од три стила напосе, које држим да ваља с обзиром на употребу времена за прошлост у нашем језику разликовати. Та су пак три стила ова: 1. стил народне пјесме, у којем обилно употребљава исторички презент имперфект. глагола а скоро никако презент перфект. глагола, 2. стил Св. писма (свечани стил), гдје се не употребљава исторички презент ни имперфект. ни перфект. глагола, 3. стил народне приповијетке (исторички стил), гдје се слабо употребљава исторички презент имперфект. а врло обилно истор. презент перфект. глагола...” (I, 113). Битна је чињеница да он даје квалификативне термине за „стилове”, који би се могли систематизовати као поетички, свечани (мајестетички) и историјски (касније назван приповедачки). Треба ипак приметити да категорија историјски (или приповедачки) „стил” није истога реда са остала два (тиче се врсте излагања, док су прве две усмерене на квалитет: в. преглед Маретићевих налаза), а то значи да Мусићева класификација није јединствена ни доследна. Али је њоме у сваком случају покренут низ питања која ни до данашњег дана нису разрешена, а по природи спадају у стилистику језичког израза (Симић 2002).

3. Рекосмо да је плурализам „стилова” остварује статистичким својствима текста, па се у даљем прегледу Мусићевих налаза на то нећемо освртати, јер је нама стало до установљења природе глаголских облика, као и до опште чиње- 
нице да они у текстовима варирају, а не до омера њиховог у датим текстовима. Мусић строго разликује употребу времена у самосталним од оне у зависним реченицама, као и „приповиједање” (П) од „разговора” (Р), тј. говор певача, одн. аутора, од говора личности кад у песми или прози узму реч.

4. „Стога треба у П разликовати двије садашњости, једну помишљену (фингирану, фиктивну), у којој се призори развијају (радње врше) [- Рано рани ђаконе Стеване], и једну праву (збиљску, реалну), у којој пјевач говори" (I, 115): - Кад сам стоја’ Гацку пространоме већ код бега Српског душманина, што рађаше од јаднијех Србах, какве њима муке удараше, сад с у мене распале пламови...

\section{1. Времена у народним песмама}

1. Прву од три студије Мусић је посветио народним песмама. У предговору излаже основне идеје, а онда их проверава у анализи грађе. О презенту најважније налазе излаже као што су овде укратко изнесени.

а) „Прави презент” описан је како је горе у т. 4 изложено.

б) Често долази презенат.. за радњу, која се понавља, и то дакако у вријеме, у које лице говори, дакле у збиљској (= правој, Р. С.) садашњости, али не у пјевачевој” (већ личности у песми): - У Индији тешко безакоње: не поштује млађи старијега, не слушају ђеца родитеља; кум свог кума на судове ћера, и доведе лажљиве сведоке, и оглоби кума вјенчанога..

в) Презент за прошлост каткада „долази у партијама у којима се што приповиједа": - Лијепа се зима намјерила, ја се дигнем, побратиме Марко, о Јовању по Божићу дану, и покупим седам, осам друга, и заведох чету од приморја, заведем је у Рудине, Марко, те уводих у Рудине овце.

2. Аорист Мусић строго двоји по значењу с обзиром налази ли се у приповедању или у разговору, те да ли је перфективан или имперфективан.

a) „Перфективну паралелу имперфективному презенту чини аорист. Ни перфективна се наиме прошла (с гледишта праве садашњости) радња у П темпорално не одређује према оном времену, у које се говори и за које је прошла, него према ономе, у које се радња врши, али ни за то вријеме она није (као имперфективна) садашња (јер перфективна радња не може бити садашња), него такођер прошла, јер се перфективна радња не може вршити, да се не изврши, и не може се извршити, да не буде прошла" (I, 120-121): - Побоље се српски цар Стјепане, у Призрену мјесту питомоме, побоље се, умријети хоће. 
б) „Аорист имперфективнога глагола значи у П, да се у помишљеној садашњости... радња... вршила и свршила": И узеше књига староставне те читаше велике молитве и држаше велика бденија за три дана и три ноћи тавне.

в) „...у Р долази у аористу радња, која се управо сада извршила у садашњости, која је... права... за лице, које говори": Ето, влаше, сад се удесисмо у по поља св'јету на видику, сад ћемо се, море, огледати.

г) Најчешће аорист у Р значи радњу, која, за лице које говори, пада у прошлост”. Али ,је тешко осјећи, мисли ли се садашњост или прошлост": Мујо пусти сивога сокола, а Алија питому журицу, уловише утву у језеру. Мујо рече: „Соко је уфати”, а Алија: „Није но журица".

д) „У Р долази кадшто аорист у значењу футура”: - Ви узмите двоје ђеце лудо, па идите двору бијеломе, а ја одох Смедереву граду молити се Ђурђу и Јерини.

3. Имперфект по Мусићу казује да је „имперфективна радња прошла за вријеме, у које пјевач говори, дакле за праву садашњост": - Доведе му без биљеге вранца, - те Максима зета дозиваше, а Милош се с коња поклањаше, те лијепо даре приваташе.

4. Разлику између перфективних и имперфективних глагола Мусић нарочито потенцира код перфекта.

a) Перфекат перф. глагола указује на „стање субјекта иза извршене... радње”. „Радња се дакако мора извршити прије, него настане њена готовост или стање... Али само вријеме њена извршења није ничим назначено, него се само по смислу погађа" (I, 128-129).

б) Када „стање, које се перфектом изриче..., може постојати већ у помишљеној садашњости, тако да се радња, иза које је настало, извршила још прије те садашњости": - Славу слави царе Костантине у прољеће честит данак Ђурђев, три је царе совре поставио (I, 130, 143).

в) „Најчешће се догађа, да извршење радње, иза којега је настало стање изречено перфектом с гледишта праве садашњости, пада у помишљену садашњост...” (?): - То је Марко послушао мајку... (I 131).

г) Ако перфекат „значи вршење радње глагола... у прошлости”, онда он „није прави перфекат”, него има „исти смисао као имперфекат” (I, 136-137). 
5. Плусквамперфекат „није ништа друго него облик перфекта метнут у претерит": - Тешко Ђемо ожеднео бјеше, Дели-Марку тихо бесеђаше.

6. Одмах нам ваља разабрати се мало у Мусићевим налазима. Подела на „праву” и „помишљену” садашњост и прошлост није непродуктивна ако се при томе мисли на категорије касније назване „индикативом”, на једној страни, и

„релативом” и „квалификативом”, одн. „апсолутивом”, на другој (Јовановић Симић 2017). Даље, није јасно, а није ни прихватљиво, када Мусић у неким случајевима перфективност тумачи као временску категорију „извршености” радње у дато време. То је заправо везано за аорист, и представља перспективу његовог значења, о чему овом приликом не треба расправљати (о томе ће бити речи у неком од будућих наших прилога).

\section{2. Времена у преводима Св. писма}

1. У расправи о временима у Св. писму неке категорије су јасније дефинисане, па ћемо цитирати та места, а иначе се нећемо подробније упуштати у резултате тога дела рада, као ни оног о нар. приповеткама.

а) Презент имперфективних глагола употребљава се „за радњу, која је садашња у вријеме, кад писац (П) или које лице (Р) говори”. „Примјера има много више у П": - Тога ради зове се студенац онај студенац живога који ме види; - него у Р: - Господе! слуга мој лежи дома, и мучи се врло (II, 71).

б) Употребљава се и „у апстрактним реченицама за радњу, која се у садашњости пишчевој (П) или говорниковој (Р) понавља": А кад видје Симон да се даје дух свети кад апостоли метну руку, донесе им новце; - А ја вам кажем да сваки који пусти жену своју, осим за прељубу, наводи је те чини прељубу; и који пуштеницу узме прељубу чини (II, 73).

2. „Аорист се употребљава за прошлу радњу, која се извршила у одређено вријеме. У П служи аорист за приповиједање, а у Р за констатирање. У Р има примјера, да се аористом (само перфективних глагола) изриче (констатира) радња, која се извршила у садашњости с гледишта оног лица, које говори...": - Кћи моја сад умрије; него дођи и метни на њу руку своју; и оживљеће (II, 74-75). „Имперфективни аорист значи (за разлику од имперфекта), да се имперфективна радња извршила, т. ј. не само вршила, него и свршила".

3. „Имперфекат се употребљава за трајну радњу, која се у прошлости у одређено вријеме или једанпут врши или понавља": - Тада излажсаше к њему Јерусалим и сва Јудеја, и сва околина Јорданска, и он их кршћаваше у Јордану, и исповиједаху гријехе своје (II, 78). 
4. „Значење..., да се њим само констатира, да се нека радња извршила, без обзира на вријеме, у које се извршила, добива перфекат по том, што се њим субјекат приказује у садашњем стању иза извршене радње, без обзира на вријеме, у које се извршила. У том (правом) свом значењу, које се слаже са значењем грчкога перфекта и онога латинскога, који се зове perfectum praesens, долази перфекат, особито од перфективних глагола, у Св. писму често": - Све је кроз њу (ријеч) постало, и без ње ништа није постало, што је постало. Али се перфекат употребљава и тако, да се више мисли на вршење радње у прошлости него на стање онога, који ју је извршио. Тако перфекат, особито перфективних глагола, добива значење прошлости. Али му од аориста и имперфекта понајвише остаје разлика, да се код перфекта не мисли на вријеме, у које се радња извршила, док се код аориста и имперфекта на то вријеме баш мисли. Тако је и онда, ако је имперфективна радња такова, да се у прошлости понавља, мисли (ако је то вријеме одређено), изриче се имперфектом, ако ли се не мисли (ако није одређено), перфектом": - Кад си био млад, опасивао си се сам, и ходио си куда си хтио (II, 80, 85-86).

5. „Плусквамперфекат казује, да је стање субјектово иза извршене глаголске радње... постојало већ у одређеној прошлости, да се дакле радња глаголска извршила још прије оне прошлости, што се има на уму” (II, 86-87).

6. И овде ваља дати извесне напомене док су нам мисли свежије.

a) Врло је значајно, а рекло би се и сасвим погођено мишљење да аорист значи радњу која се „извршила у садашњости с гледишта оног лица, које говори...” Извршеност је, рекосмо горе, временска категорија, и значи да радња аориста пада у садашњост, али да је прошла у односу на неки моменат - на моменат самог говора о њему.

б) Такође је значајан покушај да се постави граница између имперфекта и имперфективног аориста. То ће бити та „извршеност радње”?

в) Перфекат, и када не упућује на стање после извршене радње, већ на саму радњу - „само вријеме њена извршења није ничим назначено, него се само по смислу погађа".

г) Вредно је пажње и мишљење „да се код перфекта не мисли на вријеме, у које се радња извршила, док се код аориста и имперфекта на то вријеме баш мисли”. - Нама се чини да је ова разлика у ствари последица тога што аорист и имперфекат у примарном значењу означавају радњу која је локализована у садашњости, али претходи времену говорења. И онда када је значење транспоновано, остаје биполарност: локализовање у одређеној ситуацији, и прошлост према времену говорења. 


\section{3. Времена у народним приповеткама}

1. У студији о народним приповеткама Мусић се држи истих теоријских начела као и горе, па ћемо се на њих осврнути само укратко, мање да бисмо се информисали о томе, а више да проверимо већ изложено.

2.1. „Презент имперфективних глагола употребљава се:

a) за радњу која се врши у правој садашњости приповједачевој (у П: - И тако путујући један пут дуне јаки ветар и однесе галију Бог зна куда) или онога лица, које говори (у Р:- Помагај, брате, за Бога! ћера ме Брко и ево га сад ће ме стићи!).

б) за радњу, која се у правој садашњости онога лица, које говори, понавља; примјера имам само из Р [разуме се по себи]: - Куд се то дева род с наше јабуке... - Свако вече он излази из оне змијиње кошуље, а ујутру се опет у њу завлачи.

в) за радњу, која се врши у помишљеној садашњости... Примјера може бити само у П: - Кад је било око поноћи, али курјаци заурлају, а пси залају. Курјаци говоре својим језиком. - А пси одговарају својим језиком. - а то газда све слуша и разуме што причају (III, 4-5).

г) Врло ријетко презент имперфективнога глагола значи будућност, и то само у $\mathrm{P}:-$ Те ће у гору побјећи, и кад се у гори нађе, већ се дома не врће, него ће се самодавити у пустињи".

2.2. „Презент перфективних глагола употребљава се:

а) за радњу прошлу с гледишта приповједачева (исторички презент): - У некаква човекао био један чобан који га је много година верно и поштено служио. Једном идући за овцама чује у шуми неку писку).

б) За радњу која се понавља у садашњости онога лица, које говори, јер ја имам примјера само у Р: У мене има сто жена, па их свабим све на једно зрно проје кад где нађем, а кад оне дођу, ја га прождерем" (III, 6-7).

3. Аорист се употребљава:

a) „за радњу, која се у прошлости извршила на црти приповиједања: - И тако се окладише у стотину златнијех цекина, и рекоше кога најприје срету да им о томе суди (III, 8).

б) за радњу, која се извршила у вријеме, када лице говори:- Међедовић уставши полагано, распали својијем буздованом Брка у главу: а Брко прстом на оно мјесто говорећи ђевојци: „ето, овђе ме нешто уједе (III 9). 
в) Кадшто се аористом изриче будућа радња (прошла с гледишта будућег времена), али само у Р”: - За Бога, брате! молим те! умрех од жеђи; дај ми чашу воде; - ...него ја ћу узети једнога коња, једнога пса и једну сабљу па одох по свијету (III, 10).

4. „Имперфекат значи имперфективну радњу, која се врши у одређеној прошлости": - Чобан прође кроз шуму и идући чујаме и разумеваме све што говоре тице и траве (III, 10-11).

5. а) „Перфекат перфективнога глагола значи садашње стање субјектово иза извршене перф. радње”. Употребљава се „за радњу, која се извршила у прошлости с гледишта приповједачева без обзира на вријеме, када се извршила, макар то вријеме било одређено, т. ј. макар та радња падала у црту приповиједања, али мисао се не схвата као приповиједање, него као констатирање или као примједба приповједачева": - Послао отац дијете у воденицу, па му казао да не меље нигђе у воденици ђе нађе ћоca (III, 11-12).

б) „Перфекат имперфективнога глагола употребљава се... - за одређену прошлост (- Како опази њега и мараму, она уздахне, а потом точећи воду једнако је у њ гледала); - за неодређену прошлост" (- Био један цар, па имао три сина и једни кћер, коју је у кафезу хранио и чувао као очи у глави) (III, 15).

6. „Плусквамперфекат значи у П, да стање субјектово иза извршене радње глаголске постоји већ на црти приповиједања; стога се радња мора извршити још прије оних радња, што у ту црту падају; али вријеме јој није одређено. Тако се плусквамперфекат мјесто перфекта употребљава нарочито онда, да се истакне, да радња глаголска не пада у црту приповиједања, што би се код перфекта могло помислити..., него да се врши испод ње": - Она два коњика још су пре од царевог сина била дошла у двор и приповедила цару што су чули и видели (III, 15-16).

7. Поново журимо са својим коментаром док су нам мисли у Мусићевим идејама.

a) Овде Мусић долази до јасне дефиниције временског значења перфекта: да је то у основи „неодређена прошлост”, која се развила законитим развојем резултативног значења - како рече Паул, а понови и Мусић: лаганим изблеђивањем резултативности.

б) Друга ствар вредна пажње јесте да имперфекат значи радњу „која се вршила у одређеној прошлости”. „Одређеност” је свакако последица преноса примарног значења аориста и имперфекта у секундарни амбијент: са означавања садашњости непосредно пре самог говорења, на прошлост - али уз задржавање нечега од оне „непосредности” односа према говорењу. 


\section{4. Мусићеви закључци}

1. Мусић своју концепцију (III, 51. и д.) развија с поласком од историјскокомпаративних факата изнесених код Б. Делбрика.

2. Тим начином објашњава како постанак тако и значење и употребу глаголских облика.

a) На прво место он ставља проблем аориста, и разрешава подсећајући „да су првобитно, у језику праиндоевропском, за изрицање садашњости служила два облика: презент, ако је глагол имперфективан, и аорист, ако је глагол перфективан. Први је значио радњу, која се у садашњости врши, други радњу, која се у садашњости извршила. Ту службу потврђују као индоевропску језици староиндиски, ирански и грчки (исп. Delbrücka Vgl. Syun. II стр. 278. и д.), а сачувала се до у српско-хрватски језик" (III, 51).

б) „Разлика је у значењу перфекта од значења аориста и имперфекта у томе, да перфекат директно значи садашње стање субјектово иза извршене (било перфективне било имперфективне) радње, а сӓмо индиректно и са́мо вршење или извршење радње у прошлости без обзира на вријеме, аорист пак, који је од почетка значио извршење радње у одређено вријеме (у садашњости), да је с директним значењем извршења радње у прошлости спајао и значење одређенога времена тому извршењу, а за њим се повео и имперфекат, који је по њему и постао” (III, 52).

в) „Презенат имперф. глагола могао се употребљавати не само у значењу садашњости, него и у значењима у којима не значи садашњост, т. ј. у значењу прошлости и будућности..., а осим тога је... добио различна модална значења. Презенат перф. глагола, употријебљен у значењу прошлости, чини исторички презенат перф. глагола (који је по том други насљедник историчког презента имперф. глагола, а у значењу будућности стао се употребљавати, него (у подложним реченицама) као вријеме за евентуалну (најпре будућу, а онда и садашњу итеративну) радњу, као евентуални презент...” (III, 52).

3. Ако су претходна објашњења поглавито окренута значењу глаголских облика, онда се може рећи да у следећим пасажима Мусић расправља о њиховој употреби у различитим „стиловима”.

3.1. Но ту он разликује двојаке услове употребе, па о једнима суди као да „вриједе за све стилове”, а о другима као о факторима стилске варијације (III, 52-53). 
3.1.1. Што се тиче првих - он помиње две укрштене дистинкцијске линије, које деле три терминолошки експлициране појмовне вредности: „приповиједање” према „констатирању”, на једној страни, и „приповиједање” (П) према „разговору” (Р), на другој: (а) ,приповиједање и констатирање вршења неке радње разликује се тако, да се радња, која се приповиједа, изриче с обзиром на потоњу радњу (тако да се пита, што је затим било), а која се констатира, изриче се сама за се без обзира на потоњу; али приповиједање је свагдје настало од констатирања”; (б) ,приповиједање налазимо дакако поглавито у П, а констатирање у Р (али може бити приповиједања и у Р, а констатирања и у П)”. Глаголски облици се различито понашају у различитим сферама употребе како их је Мусић управо оцртао:

a) „презент имперф. глагола па аорист, имперфкат и плусквамперфекат могу се употребљавати за приповиједање и за констатирање (плусквамперфекат нарочито онакав, у којем је глагол бити у имперфекту), презент перф. глагола само за приповиједање, перфекат само за констатирање";

б) „оно, што се приповиједа, приповиједа се свагда за одређено вријеме, а оно, што се констатира, констатира се за одређено вријеме само онда, ако се изриче презентом имперф. глагола па аористом, импоерфектом или плусквамперфектом (онаким, у којем је глагол бити у имперфекту), али ако се изриче перфектом, констатира се за неодређено вријеме";

в) „одређено је вријеме у П оно, у које се једна за другом врше радње, које се приповиједају те чине црту приповиједања";

г) „имперфективна радња, која се у прошлости понавља, изриче се имперфектом, ако понављање бива у одређено вријеме, а перфектом, ако понављање бива у неодређено вријеме”.

3.2. „Стиловима” Мусић назива „начине говора” у народној песми, приповеци или преводима Св. писма. Они варирају, по Мусићу, тако што је у њима, како је већ речено, различита учесталост глаголских облика.

a) „Народна је пјесма (јуначка) [сем онога што је речено у претходним параграфима] за основу начина говора у П употријебила прадавни дуализам презента имперф. глагола и аориста за (помишљену) садашњост.., који се морао сачувати до у српско-хрватски језик, као што доказује већ његова употреба у апстрактним реченицама (гномички презент имперф. глагола, гномички аорист...)... Напосе ваља споменути, да се аорист употребљава и за констатирање прошле радње у Р, а имперфекат за приповиједање у П (мјесто презента импф. глагола) и за констатирање прошле радње у Р (како је имперфекат насљедник 
историчког презента имперф. глагола, који долази само у П, разумљиво је, да се радије употребљава у П него у Р), док перфекат служи само констатирању прошле радње у П и у Р, па стога перфекат у П и добива значај примједбе пјевачеве...” (III, 53).

б) „Народна је приповијетка прихватила презенат перф. глагола за основу начина говора у П. Али у јужним крајевима створио се други начин говора за П, којему основу чине аорист и имперфекат (Врчевићеве народне приповијетке; а тај начин налазимо и у народним пјесмама оних крајева...), док у већини народних приповиједака ти облици све више ишчезавају, а колико се још јављају, служе констатирању прошле радње. У приповијеткама, које не познају аориста и импоерфекта, може се радња, које се радња перфектом констатира без обзира на вријеме, падати у црту приповиједања (у П), т. j. у одређено вријеме, па онда перфекат перф. глагола добива у неку руку значење аориста, а перфекат имперф. глагола значење имперфекта, дакле значење времена̂, којима се вршење или извршење радње у прошлости констатира с обзиром на вријеме...” (III, 53-54).

в) „Стил Врчевићевих народних приповиједака прихватили су Вук и Даничић за пријевод Св. писма. Они дакле за основу начина говора у П употребљавају аорист и имперфекат, гдје се њима казује оно, што се приповиједа, док се у Р њима казује само оно, што се констатира за одређено вријеме (...имперфекат као и плусквамперфекат у П долазе чешће него у П...), а констатирању за неодређено вријеме служи перфекат, који ј стога обичнији у Р него у П...” (III, 54).

г) „Сами се у својим дјелима Вук и Даничић служе стилом обичне народне приповијетке, и ако [= иако] Даничић очито настоји, да оживи употребу аориста и имперфекта у извјесним границама (за констатирање прошле радње, која се врши у одређено вријеме, служи и њему перфекат)" (III, 54).

\section{5. ОПШТИ ЗАКљУЧАК}

1. Ономе што је већ речено овде ћемо дадати само неколике појединости.

2. Маретић и Мусић разликују „праву” и „неправу” садашњост, а овој ваља изгледа додати „помишљену”.

3. Ваља нарочиту пажњу посветити употреби аориста како је двојица аутора схватају. Маретићево „приопћавање” изгледа да је упоредиво са Мусићевим „констатирањем”, и да дистинкција према нпр. „приповиједању” 
- одговара оној између „историјског” и „приповедачког” презента. Овај комплекс питања потребује даља истраживања.

4. Појам „помишљене садашњости” у вези је са „апстрактним реченицама" - дакле са говором у општим категоријама, куда припадају нека објашњења и тумачења у свакодневном говору, а претежним својим делом научна и теоријска мисао уопште. Дистинкција конкретног говора према апстрактном, према томе, врло је важна између осталог и за избор глаголских облика и њихово значење у језичком изразу.

5. Скрећемо пажњу на појам „начина говора”, који смо ми назвали нешто друкчије - „начин излагања”. Код Мусића овај појам је сасвим јасно схваћен, иако није посебно дефинисан: тиче се исказивања временских односа, прошлих пре свега,помоћу аориста и имперфекта, или презента приповедачког, или перфекта. И још нешто: Мусић ту дистинкцију донекле поткрепљује, како би се то данас рекло - „жанристичким” (Јовановић и Симић 2015) аргументима: у једним случајевима реч је о приповедању, а у другима о „констатирању”. Ово су врло значајни налази које би ваљало уважити и покушати да се даље развију и теоријски истраже.

6. Мусићеви стилови подсећају на данас врло развијене расправе о функционалним стиловима, чиме се овом приликом није потребно даље бавити, али заслужује сваку пажњу.

\section{ЛИТЕРАТУРА}

Бругман и Делбрик 1893-1911: К. Brugmann und B. Delbrück, Grundriss der vergleichenden Grammatik dwer indogermanischen Sprachen, erster Theil: B. Delbrück, Vergleichende Syntax der indogermanische Sprachen, Strassburg, Karl J. Trübner 1893; zweiter Band:B. Delbrück, Lehre von den Wortformen und ihrem Gebrauch, Strassburg: Karl J. Trübner 1911.

Будмани 1867: P. Budmani, Grammatica della lingua serbo-croata, Vienna, ауторово изд.

Делбрик 1879: K. Delbrück, Die Grundlagen der griechischen Syntax. Syntaxische Forschunken IV, Halle a. S.: Verlag der Buchhandlug des Weisenhauses.

Делбрик 1919: K. Delbrück, Einleitung in das Studimu der indogermanischen Sprachen. Ein Beitrag zur Geschichte und Methodik der Vergleichenden Sprachforschung, 6. Aufl., Leipzig: Breikopf und Härtel. 
Делбрик 1893: В. Delbrück, Vergleichende Syntax der indogermanischen Sprachen, Leipzig.

Јовановић и Симић 2015: Ј. Јовановић и Р. Симић, Вербатологија (лингвистичке основе науке о вербализачији света), Београд: НДСЈ и Јасен.

Маретић 1963: T. Maretić, Gramatika hrvatskoga ili srpskoga književnog jezika, Zagreb: Matica hrvatska.

Миклошић 1883: Fr. Miklosic, Vergleichende Syntax der slavischen Sprachen, Wien: Wilhelm Braumüller.

Мусић 1892: A. Musić, Gnomički aorist u grčkom i hrvatskom jeziku, Rad JA 112.

Мусић 1902: A. Musić, Zum Gebrauche des Praesens verbi perf. im Slavischen, Archiv für slavische Philologie 24.

Мусић 1926-1927: А. Мусић, Прилози науци о употреби времена у српскохрватском језику I/II/III: Глас СКА СXXI (други разр. 66/1926), 109-173, CXXIII (други разр. 67/1927), 69-119, CXXVI (други pasp. 69/1927), 1-59.

Мусић 1932: A. Musić, Preterit futura u indoevropskim jezicima, Rad JAZ 243.

Мусић 1935: A. Musić, Slovenski efektivni prezent, Rad JAZ 253.

Паул 1956: H. Paul, Deutsche Grammatik, (1. Aufl 1920) 4. Aufl., Halle/Saale: Max Niemeyer.

Симић 1966: Р. Симић, Глаголска времена у зависним реченицама, Наш језик $\mathrm{XV}, 1-2,1-57 ; 3-4,121-157$.

Симић 2002: Р. Симић, Општа стилистика, Београд: НДСЈ и Јасен.

Симић 2016: Р. Симић, Српски правопис, Београд: НДСЈ и Јасен. 


\section{THE DOCTRINE OF EARLIER PHILOLOGISTS ON THE USE AND MEANING OF VERBAL TENSE FORMS - AND ITS IMPORTANCE}

\section{Summary}

A survey of T. Maretić's and A. Musić's doctrines indicates that the two Croatian philologists of the Vuk orientation reached a theoretically profound, and conceptually very diverse terminological system of verb form meaning and use, which is theoretically better developed, explorationally far more successful and interpretively more effective than those they inherited from the preceding scholars. It was from that platform that they analysed the language of Vuk's folk songs and tales, the Holy Writ and authorial works of these two giants of Serbian philological thought.

Radoje D. Simić 